\title{
Implicature and Presupposition of Japanese Conversation in 'Minna no Nihongo Volume II' (A Pragmatic Study)
}

\author{
Nadya Inda Syartanti, Universitas Brawijaya
}

\begin{abstract}
This study aims at describing the implicature and presupposition that occur in Japanese conversation in Minna no Nihongo Volume II. This study employs qualitative descriptive approach which will disclose the implicature and presupposition that occur in Japanese conversation in Minna no Nihongo Volume II. This study utilizes Minna no Nihongo Volume II book as the source of data, in which several conversations from chapter 26 until 50 is taken as the data. The data is gathered by 1) investigating all conversations in each chapter; 2) identifying the implicature and presupposition of the conversation in each chapter; and 3) classifying the types of implicature and presupposition in each chapter. After obtaining the data, it is analyzed by 1) describing the conversational implicature in each chapter, and 2) describing the presupposition of each conversation in each chapter.
\end{abstract}

Keywords: conversation; Japanese; implicature; pragmatics; presupposition

\section{Introduction}

Humans indeed need to interact with one another. In the interaction, there should be the means of communication, that is the use of language and a set of speech organs. One way to interact is in the form of conversation. Conversation is the face-to-face oral interaction between two or more participants and more than merely exchanging information (Samsuri, 1995: 3 in Yuniarti, 2014). A conversation is largely determined by the speaker and the hearer's context, age, gender, setting, and so on. In the conversation, pragmatics which becomes the investigation of this study is applied. The conversation between the speaker and the hearer should possess the clear meaning, purpose, and intention so that the information conveyed to the hearer can be comprehended. Understanding the meaning in an utterance becomes an essential matter which can facilitate the speaker and the hearer in comprehending the information that is delivered in the communication (Baisu, 2015). To understand the meaning in a conversation, the field of pragmatic study is required to conduct an exploration toward it. The field of study comprises; (1) language variation, (2) speech act, (3) conversation, (4) implicature, (5) deixis, (6) presupposition, (7) discourse analysis. The field of study has a narrow scope since it is based on the language use in context. The field of pragmatic study discussed in this study is the implicature and presupposition as the object of the study.

This study is limited to the implicature and presupposition of Japanese conversation in Minna no Nihongo Volume II. This study employs Minna no Nihongo Volume II book as the source of data, in which several conversations from chapter 26 until 50 of the book is taken as the data. Minna no Nihongo is chosen as the source of data since it is one of the Japanese textbooks that is most frequently used in the educational institutions like senior high school and university, not least in Universitas Brawijaya. Therefore, this study attempts to describe the implicature and presupposition that occur in Japanese conversation in Minna no Nihongo Volume II. It is expected that with this study, the learners of Japanese language are able to comprehend the meaning, purpose, and intention of Japanese conversation through the implicature and presupposition as one of the fields of pragmatic study. The data is gathered by 1) investigating all conversations in each chapter; 2) identifying the implicature and presupposition of the conversation in each chapter; and 3) classifying the types of implicature and presupposition in each chapter. After obtaining the data, it is analyzed by 1) describing the conversational implicature in each chapter, and 2) describing the presupposition of each conversation in each chapter. 


\section{Literature Review}

To understand what happens in a conversation, we need to know 1) who are engaged in it, and 2) how are the relationship and social (status) distance among the participants, such as the conversation (1) as follows.

(1) A: After this, do the others.

B: Yes, Ma'am.

The conversation (1) depicts that the social status of $\mathrm{A}$ is higher than $\mathrm{B}$. The similar thing also occurs in the conversation (2) as follows.

(2) A: Help me!

B: Can't you be patient, though?

The conversation (2) demonstrates that $\mathrm{A}$ and $\mathrm{B}$ have equal positions.

From both conversations, the utterance forms in the conversation can be formal utterance (conversation 1) and informal utterance (conversation 2) (Jumanto, 2017: 53). Formal utterance is the utterance that is employed in the situation where the speaker is being careful of the pronunciation, diction, and sentence structure, while informal utterance is also called as colloquial utterance, that is the type of utterance that is utilized in the daily informal situation where the speaker does not really concern about the pronunciation, diction, and sentence structure (Richard et al., 1985 in Jumanto, 2017: 53).

Beside the matter of formality, the utterance form in pragmatics can be the direct utterance (literal) and indirect utterance (non-literal) (Jumanto, 2017: 54). Direct uttetance usually conveys the meaning that can be directly understood from the existing linguistic context, while the meaning in the utterance does not have to be indirectly extracted through the context of existing situation, such as the example of conversation (3) as follows.

(3) A: Is there any occasion today?

B: Why?

A: Let's eat out!

B: Thanks, but I have many assignments!

In the conversation (3), there is a pre-invitation in the sentence "Is there any occasion today?" stated by A. However, B indirectly refused A's invitation to eat out. B did not said no at all, yet A understood that what was stated by B is a refusal. The expression of gratitude said by B is not the form of appreciation toward a giving, yet is a form of rejection.

(4) A: I previously apologize, Sir.

B: What's wrong, Sir?

A: I can't give you anything this time.

In the conversation (4), there is a pre-announcement in the sentence "I previously apologize, Sir." stated by A.

From both conversations, it can be seen that something expressed in a conversation will be more acceptable if there is an "opening" in it. The invitation question in the conversation (3) and apology in the conversation (4) are the introductions for the delivery of actual intention.

The form of indirect utterance can also be found in the implicit meaning, thus it is required to have the ability to apprehend the implicit meaning in an utterance, like the conversation (5) as follows.

(5) A: The trash can is full already.

B: Wait. I'm reading the newspaper first. I will dispose the trash later.

In conversation (5), A did not directly order B to dispose the trash, yet B could understand the implicit meaning in A's utterance. It can be imagined that after reading the newspaper, B will dispose the trash, since this can be inferred from B's answer. If B did not understand A's intention, the answer would be different. Imagine if B solely answered "Yes, it is."

The literal utterance (direct) has the meaning or intention that can be seen directly (explicit meaning) from the linguistic context (words in the utterance). The explicit meaning in the utterance is called as explicature. However, in a conversation, a speaker sometimes has a certain intention (implicit meaning) when uttering something. The (implicit) meaning contained in the utterance is called as implicature. 


\subsection{Implicature}

The concept of implicature was first proposed by Grice (1975). Grice (1975, in Mulyana, 2005: 11) defined implicature as the utterance that implies something that is different from what is actually uttered. That something 'different' is the speaker's intention which is not explicitly expressed. In other words, implicature is the hidden intention, desire, or expression, thus employing implicature in communication means conveying something indirectly (Rusminto, 2015: 63). Brown and Yule (in Rusminto, 2015: 63) added that implicature is utilized to consider what is suggested or intended by the speaker as something that is different from what is literally stated. If a speaker (for example, a child) says "Do you bring money?" while being in a toy store, the utterance does not merely mean to ask the hearer (for example, a father), yet it implies a wish to buy a toy.

Grice (1975, in Mulyana, 2005: 12-13) stated that there are two types of implicature. The first is conventional implicature, that is the implicature (meaning) that is general and conventional, in which people generally know the meaning of something, for example the utterance Lestari is the princess of Solo, so she is elegant. The general implication is taken from the princess of Solo and elegant. All this time, the city of Solo is always predicated as the city of culture where the princesses are elegant and fine, thus the emerged implication is that the women of Solo are generally known to have elegant appearance. Meanwhile, the second implicature is the non-conventional implicature, or better known as the conversational implicature that owns the more various meanings and intentions, where the comprehension toward the intended thing largely relies on the context where the conversation happens. Thus, the conversational implicature only occurs in a speech act. Samsuri (1988, in Rusminto, 2015: 63) added that the conversational implicature is employed to consider what can be suggested or intended by the speaker as something that is different from what literally appears, like what can be seen from the conversation (6) as follows.

(6) A: I am sleepy, too exhausted.

$\mathrm{B}$ : There is a resting place two kilometers away.

The conversation (6) depicts that $\mathrm{B}$ did not provide any direct response toward what was stated by A, but B's statement about the resting place provides the implication that A (and B) can rest for a moment before continuing their journey (Rusminto, 2015:63-64). From the explication of implicature types, this study focuses on the non-conventional implicature or the conversational implicature.

\subsection{Presupposition}

Presupposition is 'assumption, prejudice' (Nababan, 1987 in Mulyana, 2005: 14). The definition of presupposition according to Mulyana (2005: 14) is the basic assumption or inference regarding the language context and situation that renders the language form to be meaningful for the hearer. Presupposition assists the speaker to determine the language forms (sentences) to deliver the intended meaning or message. Thus, all statement or sentence expression, both positive and negative, still comprises the basic assumption as the content and substance of the sentence. Rahardi, et al. (2016: 87) added that an utterance can be said as presupposing another utterance if the truth or untruth of the presupposing sentence can be determined, for example, what is presupposed in the sentence The little kid in the big house is brilliant is that in there is a little kid who is brilliant in the big house. If there is no little kid in the big house, or if there is a little kid but is not brilliant, thus it can be said that what is presupposed in the sentence is wrong.

\section{Discussion}

From chapter 26 to 50 in Minna no Nihongo Volume II, the obtained conversation data is from chapter $26,28,38,42$, and 48 .

\subsection{Conversational Dialogue of Chapter 26}

Kanrinin : Miraa-san, hikkoshi no nimotsu wa katazukimashita ka.

Miraa : Hai, daitai katazukimashita. Ano gomi wo sutetai-ndesu ga, doko ni dashitara ii desu ka? 
Kanrinin $\quad$ : Moeru gomi wa getsu, sui, kin no asa dashite kudasai. Gomi okiba wa chuushajou no yoko desu.

\author{
Miraa : Bin ya kan wa itsu desu ka? \\ Kanrinin : Moenai gomi wa doyoubi desu. \\ Miraa $\quad$ : Hai, wakarimashita. Sorekara, oyuu ga denai-n desu ga, ... \\ Kanrinin : Gasu kaisha ni renraku shitara, sugu kite kuremasu yo. \\ Miraa $\quad \therefore$... Komatta naa. Denwa ga nain desu. Sumimasen ga, renraku shite \\ itadakemasen ka? \\ Kanrinin $\quad:$ Ee, ii desu yo. \\ Miraa : :Sumimasen, onegai shimasu.
}

The conversational dialogue of chapter 26 demonstrates the conversation between kanrinin (apartment officer) and Miraa (Miller) who just moved to the new apartment and asked several things regarding the days of garbage disposal and ordering gas tubes for hot water. One of Miller's utterances, Bin ya kan wa itsu desu ka? 'When will the bottles and cans?' implies the question that was addressed to the apartment officer about the day of bottles and cans disposal. The apartment officer's answer, Moenai gomi wa doyoubi desu 'The nonflammable trash is Saturday, implies a statement concerning the day of nonflammable garbage disposal is Saturday. Behind the utterance Bin ya kan wa itsu desu ka? and Moenai gomi wa doyoubi desu, it is implied that both Miller and the apartment officer know that bottles and cans belong to the nonflammable trash, which becomes the fact that is ascertained by both parties.

\title{
3.2 Conversational Dialogue of Chapter 28
}

Ogawa Sachiko : Miraa-san, chotto onegai ga aru-n desu ga.

Miraa : Nan desu ka?

Ogawa Sachiko: Musuko ni eigo wo oshiete itadakemasen ka? Natsu yasumi ni Oosutoraria e ikun desu ga, kaiwa ga dekinai-n desu yo.

Miraa : Oshiete agetai-n desu kedo, chotto jikan ga, ...

Ogawa Sachiko: Ocha demo nominagara oshaberishite itadakemasen ka?

Miraa $\quad: U$-n, shucchou mo ooi-shi, mou sugu nihongo no shiken mo aru-shi, ... Soreni ima made oshiete koto ga arimasen kara...

Ogawa Sachiko : Dame desu ka? Ja, zannen desu ga, ...

Miraa : Doumo sumimasen.

The conversational dialogue of chapter 28 depicts the conversation between Ogawa Sachiko, a mother who requested Miraa (Miller) to teach English to her child. One of Ogawa Sachiko's utterance, Ocha demo nominagara oshaberishite itadakemasen ka? 'What if we talk about this while drinking tea?' implies a question addressed to Miller about the tea invitation to talk about the request of teaching her child English. Miller's answer was, $U$-n, shucchou mo ooishi, mou sugu nihongo no shiken mo aru-shi, ... Soreni ima made oshiete koto ga arimasen kara... 'Mmm, I oftenly do service out of town, and I will have Japanese exam soon, ... Furthermore, I have never taught until now' implies a statement concerning Miller's condition which was quite busy with various activities, and he did not feel confident since he had never taught yet. Behind the utterance $U$-n, shucchou mo ooi-shi, mou sugu nihongo no shiken mo aru-shi, ... Soreni ima made oshiete koto ga arimasen kara..., it is implied that Miller had many activities, like doing service out of town and studying for Japanese exam, plus he did not feel confident since he had never taught before.

\subsection{Conversational Dialogue of Chapter 38}

Daigaku Shokuin: Watto Sensei, kairan desu.

Watto Sensei : A, sumimasen. Soko ni oitoite kudasai.

Daigaku Shokuin: Sensei no kenkyuushitsu wa itsumo kirei desu ne.

Watto : Watashi wa katazukeru no ga suki nan desu.

Daigaku Shokuin: Hon mo kichin to narabete aru-shi, ... Seiri suru no ga jouzu nan desu ne.

Watto : Mukashi “Jouzu na Seiri no Houhou” to iu hon wo kaite koto ga aru-n desu. 
Daigaku Shokuin: Hee, sugoi desu ne.

Watto : Amari uremasen deshita kedo ne. Yokattara, issatsu motte kimashou ka.

Daigaku Shokuin: Ohayou gozaimasu.

Watto $\quad:$ A, hon wo motte kuru no wo wasuremashita. Sumimasen.

Daigaku Shokuin: Ii desu yo. Demo, kairan ni hanko wo osu no wo wasurenaide kudasai.

Sengetsu moo shite arimasen deshita yo.

The conversational dialogue of chapter 38 shows the conversation between daigaku shokuin (campus staff) and Watto (Wat), a lecturer who has the habit of tidiness. When the campus staff entered Wat's office, the campus staff commented that his office is extremely tidy, and Wat responded that he loved tidiness. The campus staff again praised, Hon mo kichin to narabete aru-shi, ... Seiri suru no ga jouzu nan desu ne. 'Even the books are arranged neatly, you are indeed adept of book arrangement.' The campus staff's utterance implies a statement in the form of compliment that Wat is an extremely neat person, and this is revealed from his habit in book arrangement. Wat responded, Mukashi "Jouzu na Seiri no Houhou" to iu hon wo kaite koto ga aru-n desu. "I have ever written a book entitled "A Neat Arrangment Method" which implies a statement that Wat's habit in arranging things apparently has been put into a book written by himself. Behind the utterance Mukashi "Jouzu na Seiri no Houhou” to iu hon wo kaite koto ga aru-n desu, it is implied that Wat is a person who loves tidiness, in which the habit is put into a book written by himself.

\subsection{Conversational Dialogue of Chapter 42}

Suzuki

: Hayashi-san, boonasu wa itsu deru-n desu ka.

Hayashi

: Raishuu desu. Suzuki-san no kaisha wa?

Suzuki

: Ashita desu. Tanoshimi desu ne. Mazu kuruma no roon wo haratte, gorufu setto wo katte, sorekara ryokou ni itte...

Ogawa : Chokin wa shinai-n desu ka.

Suzuki : Chokin desu ka. Boku wa amari kangaeta koto arimasen.

Hayashi : Watashi wa Rondon e ryokou ni ittara, ato wa chokin shimasu.

Suzuki : Kekkon no tame ni, chokin suru-n desu ka?

Hayashi $\quad$ :Iie. Itsuka Igirisu e ryungaku shiyou to omotte iru-n desu.

Ogawa $\quad$ :Hee, dokushin no hito wa ii desu ne. Zenbu jibun no tameni, tsukaete. Watashi wa uchi no roon wo haratte, kodomo no kyouiku no tameni, chokin shitara, hotondo nokorimasen yo.

The conversational dialogue of chapter 42 demonstrates the conversation among Suzuki, Ogawa, and Hayashi as the fellow co-workers in a company, where they talked about the received bonus they will use. Suzuki's utterance Ashita desu.Tanoshimi desu ne. Mazu kuruma no roon wo haratte, gorufu setto wo katte, sorekara ryokou ni itte... 'I will pay my car payment, buy a set of golf equipment, and go on a vacation' implies that Suzuki had the desire to use her bonus to pay her car payment, to buy a set of golf equipment, and go on a vacation. When being asked by Ogawa Chokin wa shinai-n desu ka. 'Don't you save?' Suzuki answered Chokin desu ka. Boku wa amari kangaeta koto arimasen. 'Saving? I don't really think about it'. Hayashi added Watashi wa Rondon e ryokou ni ittara, ato wa chokin shimasu. 'I'm planning to go to London, then I will save'. Hayashi's utterance implies that Hayashi had a plan to go to London if she would received the bonus.Yet, Ogawa said Hee, dokushin no hito wa ii desu ne. Zenbu jibun no tameni, tsukaete. Watashi wa uchi no roon wo haratte, kodomo no kyouiku no tameni, chokin shitara, hotondo nokorimasen yo. 'It's nice to be single. You can use all for your own self. I should pay mortgage and children's education. There is almost nothing left for saving'. Behind the utterance Hee, dokushin no hito wa ii desu ne. Zenbu jibun no tameni, tsukaete. Watashi wa uchi no roon wo haratte, kodomo no kyouiku no tameni, chokin shitara, hotondo nokorimasen yo, it is implied that Ogawa is not a single individual, yet she is a person who has a family and children, in which every income should be prioritized for her family life. 


\subsection{Conversational Dialogue of Chapter 48}

$\begin{array}{ll}\text { Miraa } & \text { : Kachou, ima o-isogashii desu ka? } \\ \text { Nakamura Kachou } & \text { : Iie, douzo. } \\ \text { Miraa } & \text { : Chotto onegai ga aru-n desu ga... } \\ \text { Nakamura Kachou } & \text { : Nan desu ka? } \\ \text { Miraa } & \text { : Jitsu wa raigetsu Amerika ni iru tomodachi ga kekkon suru-n desu. } \\ \text { Nakamura Kachou } & \text { :Sou desu ka? } \\ \text { Miraa } & \text { :Sorede chotto kuni e kaerasete itadakitai-n desu ga, ... } \\ \text { Nakamura Kachou } & \text { : Raigetsu no itsu desu ka? } \\ \text { Miraa } & \text { :Shichinichi kara tooka-kan hodo yasumasete itadakemasen ka? } \\ & \text { Ryoushin ni au no mo hisashiburi na node... } \\ \text { Nakamura Kachou } & \text { :Eeto, raigetsu wa hatsuka ni eigyou kaigi ga arimasu ne. Sore } \\ & \text { madeni kaeremasu ka? }\end{array}$

\section{Miraa}

Nakamura Kachou

: Kekkonshiki wa juugo nichi na node, owattara, sugu kaette kimasu.

Miraa

: Ja, kamaimasen yo. Yukkuri tanoshinde kite kudasai.

: Arigatou gozaimasu.

The conversational dialogue of chapter 48 depicts the conversation between Nakamura Kachou (Mr. Nakamura), a boss in a division, and Miraa (Miller), a subordinate (employee) under the division of Nakamura Kachou (Mr. Nakamura). The conversation is about the application for leave permit from Miller to go home to America due to his friend's wedding invitation and meeting his parents at once. When Miller proposed his return to America next month, Mr. Nakamura's statement Eeto, raigetsu wa hatsuka ni eigyou kaigi ga arimasu ne. Sore madeni kaeremasu ka? 'Wouldn't there be a work meeting on 20th next month? Can you get back before the date?' implies that Mr. Nakamura reminded Miller that there would be a work meeting on 20th the next month and he asked Miller to get back soon before the meeting is held. Thus, there is a presupposition that there is a work meeting on 20th the next month. Miller answered Kekkonshiki wa juugo nichi na node, owattara, sugu kaette kimasu.'The wedding is held on 15th, after the wedding, I will get back soon'. Behind Miller's statement, it is implied that Miller will attend his friend's wedding in America on 15th next month.

\section{Conclusion}

From several conversations cited from Minna no Nihongo Volume II, it can be seen that each dialogue has many implicatures (implicit meanings) both spoken by the speaker and the hearer. The implicatures delivered in the dialogues emerge many presuppositions (prejudice) that can be understood from the implicatures implied in the utterances of both the speaker and the hearer.

\section{References}

Baisu, L. 2015. Praanggapan Tindak Tutur Dalam Persidangan Di Kantor Pengadilan Negeri Kota Palu. e-Jurnal Bahasantodea, 3(2), 129-143.

Chan, M. 2013. Bentuk-bentuk Pragmatik. Available at https://othersidemiku.wordpress.com/2013/05/29/bentuk-bentuk-pragmatik-1/

(Accessed 6 June 2018).

Hirai, E., \& Miwa, S. 2012. Minna no Nihongo Shokyuu II Honsatsu. Tokyo: 3A Network.

Jumanto. 2017. Pragmatik: Dunia Linguistik Tak Selebar Daun Kelor. Yogyakarta: Morfalingua.

Mulyana. 2005. Kajian Wacana: Teori, Metode, dan Aplikasi Prinsip-Prinsip Analisis Wacana. Yogyakarta: Tiara Wacana.

Rahardi, K., Setyaningsih, Y., \& Dewi, R. P. 2016. Pragmatik: Fenomena Ketidaksantunan Berbahasa. Jakarta: Penerbit Erlangga.

Rusminto, N. E. 2015. Analisis Wacana: Kajian Teoritis dan Praktis. Yogyakarta: Graha Ilmu.

Yuniarti, N. 2014. Implikatur Percakapan Dalam Percakapan Humor. Jurnal Pendidikan Bahasa, 3(2), 225-239. 